\title{
Entrepreneurial Mindset: A Synthetic Literature Review
}

\author{
Christiane Naumann
}

\begin{tabular}{l} 
A B S T R A C T \\
Objective: The objective of this paper is to provide an overview of the state-of-the- \\
art in research on entrepreneurial mindset (EM). The paper identifies research areas \\
which have contributed to the current status of the EM concept, outlines areas which \\
remain under-addressed and suggests areas for future research. \\
\hline Research Design \& Methods: A comprehensive method of a synthetic literature review \\
was employed. In a four-step process, relevant papers were identified and classified. Re- \\
search methods and sampling were analysed and put into a perspective of the EM con- \\
cept development. Based on that, recommendations for future research are presented. \\
\hline Findings: No commonly shared EM concept was found. Instead, scholars have con- \\
tributed largely by depicting particular attributes of EM. These attributes can be di- \\
vided into core attributes of EM and meta-cognitive attributes of EM. While core at- \\
tributes are easier to recognize and exhibited through behaviour, meta-cognitive at- \\
tributes are more hidden within an individual. Mainly the Anglo-American perspec- \\
tive influences the research on EM. The dominating research design methods remain \\
quantitative. Only one longitudinal and one qualitative study using in-depth inter- \\
views were identified in the pool. Links to other research areas are provided. \\
\hline Implications \& Recommendations: The EM concept might be investigated further \\
with the inclusion of more other cultures or with people from other cultural back- \\
grounds to test the validity of the existing assumptions. \\
\hline Contribution \& Value Added: This literature review contributes to the current body \\
of knowledge by giving an overview of the EM concept and its attributes and as- \\
sociated qualities. It identifies current gaps in research and provides recommen- \\
dations on how to close them. \\
\hline Article type: $\quad$ literature review \\
Keywords: $\quad$ ability; cognitive tuning of mindsets; literature review \\
JEL codes: \\
Received: 6 June $2017 \quad$ Revised: 8 July 2017 \\
\hline
\end{tabular}

\section{Suggested citation:}

Naumann, C. (2017). Entrepreneurial Mindset: A Synthetic Literature Review. Entrepreneurial Business and Economics Review, 5(3), 149-172. http://doi.org/10.15678/EBER.2017.050308 


\section{INTRODUCTION}

Ever since researchers in the area of entrepreneurship started to explore the field of entrepreneurial mindset, they were intrigued by the questions why some people identify opportunities and others do not. And doing so, how they are able to leverage and combine existing and new resources in an innovative way given dynamic and complex environments. The approach to answer these questions shifted considerably over time, coming from two very different viewpoints. The first approach was based on personal characteristics of the entrepreneur, assuming there must be special "traits" which explain the ability to identify and explore new opportunities. However, research on these traits lead to unconvincing and weak results (Busenitz \& Barney, 1997; Gartner, 1989; Mitchell, 2007; Shaver \& Scott, 1991) and scholars argued that the research problem must be addressed from another angle, one which it based on cognition and stipulates entrepreneurship as a way of thinking (Gartner, 1989; Palich \& Bagby, 1995; Shaver \& Scott, 1991). Thus, entrepreneurs are not "born" with specific traits. It is their entrepreneurial mindset (EM) that makes them different. Yet mindsets are not given, they evolve over time and are influenced by an individual's interaction with the environment (Mathisen \& Arnulf, 2013).

Vast and growing body of knowledge regarding EM addresses the challenges of coping with and adapting to complexity and dynamic and uncertain environments. This concept is not only relevant in the context of entrepreneurship, but also in the overall business environment. Complexity and uncertainty are not an exception, but the standard in today's business world. If an entrepreneurial mindset can be learned and developed, it could positively impact companies' survival.

During the last two decades scholars have unpacked pieces of EM and provided valuable insights into its working, its attributes and associated qualities. However, they did not put the pieces together to provide a full picture. Moreover, different perspectives on EM itself have led to a different focus. While the meta-perspective argues that EM is meta-cognitive in nature (Haynie, Shepherd, Mosakowski, \& Earley, 2010; Haynie \& Shepherd, 2007), other authors explore single attributes of EM which influence how entrepreneurs think, adapt and act (Baron, 1998, 2006; Busenitz \& Barney, 1997; Shane \& Venkataraman, 2000; Venkataraman, 1997).

Given the different perspectives and dimensions of EM, a meta-analysis of the concept is important to provide an overview of the state-of-the-art in research and an overall picture of factors influencing EM.

This study aims to identify the contributing research areas and perspectives of EM, suggest bridges in between to provide the state-of-the-art in the EM concept and outline those areas that remain under-addressed.

The method employed for this study was a synthetic literature review which followed a multi-step process to come up with the final list of papers for the review. The databases used were (i) ScienceDirect, (ii) Emerald Insight and (iii) Scopus, as they contain the 'mainstream' of research papers in English.

This study contributes to current body of knowledge by providing an overview of the contemporary understanding of the EM concept, its attributes and associated qualities. It outlines implications for practice and how this concept can be linked to 
other concepts in entrepreneurial research, points to areas which need further research and gives recommendations on how to close them.

The paper starts with a description and reasoning of the review process used for this research. It classifies the reviewed papers first into research streams and second, into the types of papers to provide an overview. It explains their geographical context, the methods and samples used and gives an overview of the research design used. Next, the dominating components of EM are described and the EM theory development presented. Finally, the review will sum up with conclusions, limitations of recent development and recommendation for future research.

\section{MATERIAL AND METHODS}

The method applied to this research was a critical and comparative analysis of the existing published research results. The selection of the pool of papers which were included in the analysis was a multi-step process.

A comprehensive screening of the term "entrepreneurial mindset" was done in the databases of (i) ScienceDirect, (ii) Emerald Insight and (iii) Scopus. The screening applied four steps and resulted in four lists A-D (Figure 1).

The first screening led to List " $A$ " which contained 712 papers. Limiting the search of the exact term to the abstract then reduced this list " $B$ " to 233 articles. In further reduction, the search for the exact term was narrowed down to headlines and the key words "entrepreneurial mindset" outlined by authors for their articles as this assumes that the term is the central concept of their paper. List " $B$ " then consisted of 38 papers only. In the next step, an initial review of the papers was done including the abstract and conclusions, the definitions provided and the area of interest. The area of interest evolved to be either in the conceptualisation of EM or in practical application in the field of education. While conceptualisation seeks to understand the concept per se, education is applying it to enhance the teaching of entrepreneurship. As the focus of this paper is the review of current literature on the concept of EM, its definition and related attributes, articles related to education were eliminated from the list as well as those which doubled across the databases. List " $C$ " then consisted of 8 only articles. When reviewing these 8 papers, it emerged that the conceptualisation of EM seemed to have a cognitive-based perspective (Haynie, Shepherd, Mosakowski, \& Earley, 2010; Mathisen \& Arnulf, 2013; McGrath \& MacMillan, 2000; McMullen \& Kier, 2016; Shepherd, Patzelt, \& Haynie, 2010), although some authors linked this cognitive view also to personal traits (Ashourizadeh, Chavoushi, \& Schøtt, 2014; Davis, Hall, \& Mayer, 2015; Dhliwayo \& Van Vuuren, 2007; Ngek, 2012). However, no common overall understanding of the EM concept emerged across the initial articles and no overview of its attributes and associated qualities was given. Thus, further research was necessary. The 8 articles were then analysed for three criteria: (a) the key theory referenced for their conceptualisation, (b) references to other papers for EM attributes and (c) references to EM definitions. This approach led to additional 16 papers which were included into " $D$ " list. Again, these 16 papers were analysed for the same 3 criteria leading to 3 more articles which were added. Additionally, the databases were scanned for those authors who seemed to be central in that research stream and their papers reviewed for the relevance to this 
literature review. Through this, 3 more articles were added. In total, 22 papers were added to the initial 8.

\begin{tabular}{|c|c|c|c|}
\hline \multicolumn{4}{|c|}{ Screening of literature for the term "Entrepreneurial Mindset" } \\
\hline \multicolumn{4}{|c|}{$\downarrow$} \\
\hline "A"-list & Science Direct & Emerald Insight & Scopus \\
\hline \# of articles using the term in the text & 231 & 266 & 215 \\
\hline \multicolumn{4}{|l|}{ 5. } \\
\hline \multirow{2}{*}{\multicolumn{4}{|c|}{$\begin{array}{c}\text { Reduction: search for the term "Entrepreneurial Mindset" in abstract and headline } \\
\downarrow\end{array}$}} \\
\hline & & & \\
\hline "B"-list & Science Direct & Emerald Insight & Scopus \\
\hline $\begin{array}{l}\text { \# of articles using the term in the } \\
\text { abstract }\end{array}$ & 17 & 23 & 193 \\
\hline \multicolumn{4}{|l|}{ 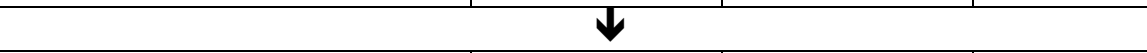 } \\
\hline $\begin{array}{l}\text { \# of articles using the term in the } \\
\text { headline \& the key words }\end{array}$ & 7 & 6 & 25 \\
\hline \multicolumn{4}{|l|}{ 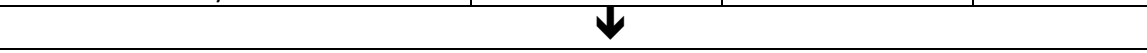 } \\
\hline \multicolumn{4}{|c|}{ Review \& Reduction: abstract + conclusion + definition provided + concept presented on EM } \\
\hline "C"-list & Science Direct & Emerald Insight & Scopus \\
\hline $\begin{array}{l}\text { Articles related to the } \\
\text { conceptualisation of EM }\end{array}$ & 3 & 1 & 4 \\
\hline $\begin{array}{l}\text { Articles related to the application of } \\
\text { the EM concept for Entrepreneurial } \\
\text { Education }\end{array}$ & 3 & 2 & 1 \\
\hline $\begin{array}{l}\text { Other articles not relevant for the } \\
\text { paper }\end{array}$ & 1 & 3 & 20 \\
\hline \multicolumn{4}{|c|}{$\downarrow$} \\
\hline \multicolumn{4}{|c|}{ Reference to key literature as the basis for theory building added to list } \\
\hline "D"- list & Science Direct & Emerald Insight & Scopus \\
\hline Relevant articles from "C"-list & 3 & 1 & 4 \\
\hline Additional articles for review & \multicolumn{3}{|c|}{22} \\
\hline Additional "trait-based" articles & \multicolumn{3}{|c|}{3} \\
\hline
\end{tabular}

Figure 1. The process applied for literature review Source: own study.

To provide a more comprehensive picture of the state-of-the-art, also 3 articles related to the entrepreneurial trait theory were included which were referenced by Palich and Bagby (1995) and Shaver and Scott (1991). The final list “D” consisted of 33 articles (Table 1).

The final list of 33 papers contained 3 articles not focusing on the entrepreneurial mindset but on the mindset per se (Gollwitzer, 1990; Gollwitzer, Heckhausen, \& Steller, 1990; Gollwitzer \& Kinney, 1989). As these papers formed a relevant basis for the conceptualisation of the entrepreneurial mindset later on by McMullen and Kier (2016) and Mathisen and Arnulf (2013), they were seen as important for the analysis of where we are today in the understanding of the EM concept. 
Table 1. List "D" constituting the final pool of papers for review

\begin{tabular}{|c|c|c|c|}
\hline \multirow{2}{*}{ Initial articles List “C” (8) } & \multicolumn{3}{|c|}{ Criteria for additional articles for review for List "D" } \\
\hline & $\begin{array}{c}\text { Reference to key theory for own } \\
\text { conceptualisation }\end{array}$ & Reference to EM attributes & Reference to EM definition \\
\hline McMullen \& Kier (2016) & $\begin{array}{l}\text { Gollwitzer \& Kinney (1989) } \\
\text { Gollwitzer (1990) } \\
\text { Gollwitzer et al., (1990) }\end{array}$ & $\begin{array}{l}\text { Baron (1998), Kirzner (1973), } \\
\text { Haynie et al., (2012) }\end{array}$ & Ireland et al. (2003) \\
\hline Haynie et al., (2010) & Shane \& Venkataram (2000) & $\begin{array}{l}\text { Shane (2000), Alvarez \& Busenitz } \\
\text { (2001), Busenitz \& Barney (1997), } \\
\text { Mitchell \& Busenitz (2002) }\end{array}$ & McGrath \& MacMillan (2000) \\
\hline McGrath \& MacMillan (2000) & & - & - \\
\hline Shepherd et al., (2010) & Haynie \& Shepherd (2007) & - & Haynie \& Shepherd (2007) \\
\hline Ashourizadeh (2014) & & - & Ireland et al., (2003) \\
\hline Ngek (2012) & Dhliwayo \& Van Vuuren (2007) & Simon et al., (2000) & $\begin{array}{l}\text { Dhliwayo \& Van Vuuren (2007), } \\
\text { McGrath \& MacMillan (2000) }\end{array}$ \\
\hline Davis et al., (2016) & Gartner (1988) & - & - \\
\hline Simon et al., (2000) & $\begin{array}{l}\text { Shaver \& Scott (1991) } \\
\text { Palich \& Bagby (1995) }\end{array}$ & r & - \\
\hline Authors added by further research & Mitchell et al., (2007) & Baron (2006) & Baron (2014) \\
\hline Additional articles for review & 3 & 20101,12004 & 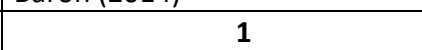 \\
\hline $\begin{array}{l}\text { Sum additional articles for review } \\
\text { added to initial } 8\end{array}$ & 10 & 10 & 2 \\
\hline $\begin{array}{l}\text { Shaver \& Scott (1991) } \\
\text { Palich \& Bagby (1995) }\end{array}$ & $\begin{array}{l}\text { Brockhaus }(1980) \\
\text { McClelland }(1961 ; 1987)\end{array}$ & - & - \\
\hline Additional articles "trait-based" & 3 & - & - \\
\hline
\end{tabular}

Source: own study. 


\section{FINDINGS AND DISCUSSION}

\section{Types of Papers}

The review revealed several categories of papers. These papers were classified twofold to provide a precise overview of the state-of-the-art (Table 2). The first classification was the research stream. The review revealed two major sub-streams in EM research: the cognitive- and the trait-based approach. However, some scholars were also combining the two approaches, which will be referred to as "Combined". The second classification was the types of papers in four different categories, depending on the overall goal of the study. Category one is the systematic review. These authors reviewed previous research papers, worked out the gaps in research and recommended areas for future research. Category two is conceptual. In these papers authors reviewed existing papers and built a new theory or framework onto it to close an existing gap in the literature. These papers were entirely theoretical and the concept was not tested therein. Category three is explanatory. The authors of these papers used surveys to explain the existing phenomena in the EM field empirically. They conducted quantitative research using self-reported questionnaires which measured opinions of participants with Likert scales. Category four is exploratory and also empirical. It is divided into experimental research design (E) and in-depth interviews (IDI). Scholars used experiments to explore behaviour of participants in a laboratory setting. Tasks conducted by the participants were observed and their behaviour interpreted. Based on the results, a model was developed. The in-depth interviews were conducted to get insights of the mindset of the participants and the results were also used for modelling.

In total, 17 of the papers were theoretical and 16 empirical. Among the empirical papers, 10 were explanatory and 6 were exploratory. $95 \%$ of the empirical papers engaged with participants a single point in time (SP). Only once there was explanatory research done with a longitudinal design $(\mathrm{L})$ engaging with the same individuals (students) with a week of interval.

\section{Samples Used in Empirical Research}

An overview of the samples used helps to put the results of the publications into perspective. Table 3 presents the three target groups addressed in the three research areas. In the EM field of research, the main group focused on was students, followed by entrepreneurs, managers and adults. Managers were taken for comparison: Busenitz and Barney (1997) compared managers with 124 entrepreneurs with a business experience of 1.7 years on average to test differences in the use of heuristics and biases in their decision logic. Davis et al., (2016) created an Entrepreneurial Mindset Profile measure in a three-step development process with different questionnaires comparing managers and entrepreneurs. McClelland (1961) investigated the traits that differentiate entrepreneurs from managers. Brockhaus (1980) compared entrepreneurs who founded a business with managers who changed between or within an organisation in the last 3 months.

Adults were chosen by Ashourizadeh et al., (2014) in a survey in the Global Entrepreneurship Monitor to test whether confidence in innovation is positively influencing the intention to become an entrepreneur. 
Table 2. Classification of papers

\begin{tabular}{|c|c|c|c|c|}
\hline Approach & $\begin{array}{l}\text { Systematic } \\
\text { review }\end{array}$ & Conceptual & Explanatory & Exploratory \\
\hline $\begin{array}{l}\text { Cognitive- } \\
\text { based } \\
\text { (EM) }\end{array}$ & $\begin{array}{l}\text { Gartner } \\
\text { (1989) } \\
\text { Mitchell et } \\
\text { al., (2007) }\end{array}$ & \begin{tabular}{|l|} 
Kirzner (1973) \\
Shaver \& Scott (1991) \\
Venkataram (1997) \\
Baron (1998) \\
Shane \& Venkataram (2000) \\
McGrath \& MacMillan (2000) \\
Alvarez \& Busenitz (2001) \\
Mitchell \& Busenitz (2002) \\
Ireland et al., (2003) \\
Baron (2006) \\
Haynie et al., (2010) \\
Shepherd et al., (2010) \\
Baron (2014) \\
McMullen \& Kier (2016)
\end{tabular} & $\begin{array}{l}\text { SP: } \\
\text { Palich \& Bagby (1995) } \\
\text { Busenitz \& Barney } \\
\text { (1997) } \\
\text { Haynie et al., (2009) } \\
\text { Mathisen \& Arnulf } \\
\text { (2009) } \\
\text { L: } \\
\text { Simon et al., (2000) }\end{array}$ & $\begin{array}{l}\text { E: } \\
\text { Gollwitzer \& } \\
\text { Kinney (1989) } \\
\text { Gollwitzer } \\
(1990) \\
\text { Gollwitzer et al., } \\
(1990) \\
\text { Haynie \& Shep- } \\
\text { herd (2007) } \\
\text { Haynie et al., } \\
(2012) \\
\text { IDI: } \\
\text { Shane (2000) }\end{array}$ \\
\hline Combined & - & $\begin{array}{l}\text { Dhliwayo \& Van Vuuren } \\
\text { (2007) }\end{array}$ & $\begin{array}{l}\text { Ashourizadeh (2014) } \\
\text { Ngek (2015) } \\
\text { Davis et al., (2016) }\end{array}$ & - \\
\hline Trait based & - & - & $\begin{array}{l}\text { McClelland }(1961 ; 1987) \\
\text { Brockhaus }(1980)\end{array}$ & - \\
\hline
\end{tabular}

Notes: SP: Single point in time, L: Longitudinal, E: Experimental research design, IDI: In-depth interviews. Source: own study.

Table 3. Overview of target groups for explanatory and exploratory research

\begin{tabular}{|c|c|c|c|c|}
\hline \multicolumn{1}{|c|}{ Approach } & Students & Entrepreneurs & Managers & Adults \\
\hline Cognitive-based (EM) & $\mathbf{8}$ & $\mathbf{3}$ & $\mathbf{1}$ & $\mathbf{0}$ \\
\hline Explanatory & 5 & 2 & 1 & 0 \\
\hline Exploratory & 3 & 1 & 0 & 0 \\
\hline Combined & $\mathbf{0}$ & $\mathbf{2}$ & $\mathbf{1}$ & $\mathbf{1}$ \\
\hline Explanatory & 0 & 2 & 1 & 1 \\
\hline Exploratory & 0 & 0 & 0 & 0 \\
\hline \multicolumn{1}{|c|}{ Traits } & $\mathbf{0}$ & $\mathbf{3}$ & $\mathbf{2}$ & $\mathbf{0}$ \\
\hline Explanatory & 0 & 3 & 2 & 0 \\
\hline Exploratory & 0 & 0 & 0 & 0 \\
\hline
\end{tabular}

Source: own study.

\section{Geographical Context of Empirical Studies}

Looking at the geographical origin of the papers analysed in this review, $85 \%$ are published by American scholars. That means that EM 'mainstream' research takes mainly an Anglo-American perspective.

$50 \%$ of the exploratory research papers are from the US, whereof only one scholar made use of interviews with entrepreneurs from start-ups (Shane, 2000) and the others relied on experiments with students. The only experiments carried out outside the US were carried out in Germany by Gollwitzer and Kinney (1898), Gollwitzer (1990) and 


\begin{tabular}{|c|c|c|c|}
\hline Author & Focus of study & 1. Sample, 2. Method, 3. Geographics & Conclusion(s) \\
\hline \multicolumn{4}{|c|}{ Explanatory } \\
\hline \multicolumn{4}{|c|}{ Cognitive-based EM } \\
\hline $\begin{array}{l}\text { Palich \& } \\
\text { Bagby } \\
(1995)\end{array}$ & $\begin{array}{l}\text { Deliberate whether the process of } \\
\text { cognitive categorisation for } \\
\text { disputable data is special for } \\
\text { entrepreneurs. }\end{array}$ & $\begin{array}{l}\text { 1. } 148 \text { members of a business } \\
\text { organisation } \\
\text { 2. Quantitative, e-mail questionnaire } \\
\text { 3. Not mentioned (assumed US) } \\
\end{array}$ & $\begin{array}{l}\text { Confirm cognitive categorisation of entrepreneurs: they } \\
\text { access categories which propose more favourable } \\
\text { attributes and thus present opportunities instead of risk. }\end{array}$ \\
\hline $\begin{array}{l}\text { Busenitz \& } \\
\text { Barney } \\
(1997)\end{array}$ & $\begin{array}{l}\text { Find out how entrepreneurs and } \\
\text { managers of large organisations differ } \\
\text { in their decision-making processes. }\end{array}$ & $\begin{array}{l}\text { 1. } 124 \text { entrepreneurs average time } \\
\text { since founding } 1.7 \text { years, managers } \\
\text { 2. Quantitative, questionnaire } \\
\text { 3. Not mentioned (assumed US) } \\
\end{array}$ & $\begin{array}{l}\text { Entrepreneurs are not risk-takers per se, they might } \\
\text { perceive the risk in a situation differently based on the } \\
\text { heuristics they use. }\end{array}$ \\
\hline $\begin{array}{l}\text { Simon, } \\
\text { Houghton } \\
\text { \& Aquino } \\
(2000)\end{array}$ & $\begin{array}{l}\text { Understand the influences on risk } \\
\text { perception. Relationship between risk } \\
\text { perception and decision to start a new } \\
\text { venture. Determine the influence of } \\
\text { cognitive biases on the perceived risk } \\
\text { level. }\end{array}$ & $\begin{array}{l}\text { 1. } 191 \text { Master students } \\
\text { 2. Longitudinal with } 2 \text { tests with a week } \\
\text { in between using a survey with } 10 \\
\text { questions } \\
\text { 3. US }\end{array}$ & $\begin{array}{l}\text { It could not be proved that overconfidence influences risk } \\
\text { perception but statistical significance was shown for illusion } \\
\text { of control and law of small numbers - both lowered risk } \\
\text { perception. However the mediator role of risk perception in } \\
\text { the decision to start a venture only partially proven. }\end{array}$ \\
\hline $\begin{array}{l}\text { Mathisen } \\
\text { \& Arnulf } \\
(2013)\end{array}$ & $\begin{array}{l}\text { Make contribution to individual level } \\
\text { capability theory. }\end{array}$ & $\begin{array}{l}\text { 1. } 242 \text { undergraduate students with } \\
\text { average work experience of } 4.6 \text { years } \\
\text { 2. Quantitative: } 16 \text {-item scale to } \\
\text { measure } 2 \text { entrepreneurial mindsets } \\
\text { 3. Norway }\end{array}$ & $\begin{array}{l}\text { Entrepreneurial mindsets differ depending on the state the } \\
\text { individual is in: elaborative and implemental. Two } \\
\text { mindsets lead to differing decision-making capabilities. }\end{array}$ \\
\hline \multicolumn{4}{|c|}{ Combined } \\
\hline $\begin{array}{l}\text { Ashouriza } \\
\text { deh, } \\
\text { Chavoushi }\end{array}$ & $\begin{array}{l}\text { Proof that confidence in innovation } \\
(\mathrm{Cl}) \text { is a major component of EM } \\
\text { which positively influences the }\end{array}$ & $\begin{array}{l}\text { 1. } 384,444 \text { adults } \\
\text { 2. Quantitative: Survey in the Global } \\
\text { Entrepreneurship Monitor } \\
\text { 3. } 71 \text { societies included in the GEM }\end{array}$ & $\begin{array}{l}\mathrm{Cl} \text { is part of EM. It is linked to other factors, here traits like } \\
\text { risk-propensity and self-efficacy. } \\
\text { Culture influences the } \mathrm{Cl} \text {, which affects the intention to } \\
\text { become an entrepreneur. }\end{array}$ \\
\hline
\end{tabular}




\begin{tabular}{|c|c|c|c|}
\hline $\begin{array}{l}\text { Ngek } \\
(2012)\end{array}$ & $\begin{array}{l}\text { Assessing the level of EM in the } \\
\text { Bloemfontain area in South Africa } \\
\text { through measuring EM with the } \\
5 \text { characteristic stipulated by } \\
\text { McGrath and MacMillan (2000). }\end{array}$ & $\begin{array}{l}\text { 1. } 86 \text { entrepreneurs in the SME sector } \\
\text { 2. Quantitative: self-administered } \\
\text { questionnaire } \\
\text { 3. South Africa }\end{array}$ & $\begin{array}{l}\text { Supports the link between traits as creativity, motivation } \\
\text { and risk-propensity to the characteristics of EM as } \\
\text { proposed by McGrath and MacMillan (2000). EM can be } \\
\text { increased through entrepreneurial education to lower the } \\
\text { failure rate of new ventures. }\end{array}$ \\
\hline $\begin{array}{l}\text { Davis, Hall } \\
\& \text { Mayer } \\
(2014)\end{array}$ & $\begin{array}{l}\text { Develop a measure of EM } \\
\text { (EM Profile) and provide } \\
\text { implications for practitioners. }\end{array}$ & $\begin{array}{l}\text { 1. Managers (300) and entrepreneurs } \\
\text { (725) plus 1,872 unspecified } \\
\text { 2. Quantitative, online: Version A } 118 \\
\text { items on 14-scales, Version B } 115 \\
\text { items on 14-scales, Version C } 72 \\
\text { items on 14-scale } \\
\text { 3: Tampa- St. Petersburg }\end{array}$ & $\begin{array}{l}\text { EMP measure that makes up } 7 \text { dimensions each on traits } \\
\text { and skills, whereas traits have a stronger effect on } \\
\text { entrepreneurial status. Men and women scored differently } \\
\text { on the dimensions. } \\
\text { In relation to Big Five traits, Openness to Experience had } \\
\text { the strongest association with the EMP scales, Extraversion } \\
\text { the weakest. }\end{array}$ \\
\hline \multicolumn{4}{|r|}{1} \\
\hline $\begin{array}{l}\text { McClellan } \\
\text { d (1961) }\end{array}$ & $\begin{array}{l}\text { What differentiates entrepreneurs } \\
\text { from non-entrepreneurs in their } \\
\text { need for achievement. }\end{array}$ & $\begin{array}{l}\text { 1. Middle level managers } \\
\text { 3. US, Turkey, Italy, Poland, India }\end{array}$ & $\begin{array}{l}\text { Need for achievement is related to moderate risk taking - } \\
\text { people who have a high need prefer working on challenges } \\
\text { with moderate risk. } \\
\text { Need for achievement also related to preference of } \\
\text { responsibility. } \\
\text { Points at causal relationship between the need for } \\
\text { achievement and entrepreneurial success. }\end{array}$ \\
\hline $\begin{array}{l}\text { McClellan } \\
\text { d (1967) }\end{array}$ & $\begin{array}{l}\text { Characteristics of successful } \\
\text { entrepreneurs. }\end{array}$ & $\begin{array}{l}\text { 1. } 24 \text { owners of small business people } \\
\text { ( } 12 \text { successful, } 12 \text { average) } \\
\text { 3. India, Malawi, Ecuador }\end{array}$ & $\begin{array}{l}\text { No specialty identified for successful entrepreneurs } \\
\text { characteristics like self-confidence, expertise, } \\
\text { persuasion, persistence. }\end{array}$ \\
\hline $\begin{array}{l}\text { Brockhaus } \\
(1980)\end{array}$ & $\begin{array}{l}\text { Comparison of risk taking } \\
\text { propensity between entrepreneurs } \\
\text { and managers. }\end{array}$ & $\begin{array}{l}\text { S: } 3 \text { groups: } 1 \text {. Started own business in } \\
\text { the last } 3 \text { months; } 2 \text {. Managers who } \\
\text { changed organisation within last } \\
3 \text { months; } 3 \text {. Managers who } \\
\text { changed within organisation } \\
\text { within the last } 3 \text { months } \\
\text { M: quantitative, questionnaire } \\
\text { G: US }\end{array}$ & $\begin{array}{l}\text { It could not be sufficiently proved that this } \\
\text { characteristic is special for entrepreneurs. }\end{array}$ \\
\hline
\end{tabular}




\begin{tabular}{|c|c|c|c|}
\hline Author & Focus of study & 1. Sample, 2. Method, 3. Geographics & Conclusion(s) \\
\hline \multicolumn{4}{|c|}{ Exploratory } \\
\hline \multicolumn{4}{|c|}{ Cognitive-based EM } \\
\hline $\begin{array}{l}\text { Gollwitzer \& } \\
\text { Kinney } \\
(1989)\end{array}$ & $\begin{array}{l}\text { Effects on illusion of control by } \\
\text { different mindsets. }\end{array}$ & $\begin{array}{l}\text { 1. A. } 64 \text { male students, B. } 61 \text { female students } \\
\text { 2. Experiment } \\
\text { 3. Munich, Germany }\end{array}$ & $\begin{array}{l}\text { Mindsets affect cognitive functioning, the more } \\
\text { determined individuals are in implementation } \\
\text { (thus being in implemental mindset), the more } \\
\text { illusionary judgement of control. }\end{array}$ \\
\hline $\begin{array}{l}\text { Gollwitzer, } \\
\text { Heckhausen, } \\
\text { \& Steller } \\
\text { (1990) }\end{array}$ & $\begin{array}{l}\text { Explore whether mindsets are } \\
\text { cognitively tuned to the task } \\
\text { at hand. }\end{array}$ & $\begin{array}{l}\text { 1. A. } 97 \text { male students, B. } 69 \text { male students } \\
\text { 2. Experiment } \\
\text { 3. A. Bochum, B. Munich, both Germany }\end{array}$ & $\begin{array}{l}\text { Congruence between mindset and thought } \\
\text { production (cognitive process) to solve a task at } \\
\text { hand efficiently. }\end{array}$ \\
\hline $\begin{array}{l}\text { Gollwitzer } \\
\text { (1990) }\end{array}$ & $\begin{array}{l}\text { Explore the characteristics of } \\
\text { mindsets in each of the action } \\
\text { phases. }\end{array}$ & $\begin{array}{l}\text { Refers to experiments in previous works, } \\
\text { e.g. Gollwitzer \& Kinney } 1989 .\end{array}$ & $\begin{array}{l}\text { Goal oriented behaviour is not the same in each } \\
\text { of the phases and thus mindsets. Every phase has } \\
\text { own principles. There is a clear distinction between } \\
\text { mindsets in goal setting and goal striving. }\end{array}$ \\
\hline $\begin{array}{l}\text { Haynie, } \\
\text { Shepherd, \& } \\
\text { Patzelt (2012) }\end{array}$ & $\begin{array}{l}\text { Contributing to entrepreneurial } \\
\text { decision-making literature; } \\
\text { understanding the role of } \\
\text { feedback on decision-making. }\end{array}$ & $\begin{array}{l}\text { 1. A. } 217 \text { undergraduate business students } \\
\text { B. } 73 \text { experienced entrepreneurs } \\
\text { 2. Laboratory experiment, 11-point-Likert scale } \\
\text { 3. US }\end{array}$ & $\begin{array}{l}\text { Inexperienced individuals who use meta-cognitive } \\
\text { resources (knowledge and experience) process } \\
\text { feedback more effectively. Meta-cognitive abilities } \\
\text { represent an important factor for performance. }\end{array}$ \\
\hline Shane (2000) & $\begin{array}{l}\text { Conceptual model that is based } \\
\text { on the assumption that } \\
\text { opportunities are related to } \\
\text { knowledge available for } \\
\text { individuals. }\end{array}$ & $\begin{array}{l}\text { 1. } 8 \text { entrepreneurs using the same technology } \\
\text { base } \\
\text { 2. Interviews } \\
\text { 3. US }\end{array}$ & $\begin{array}{l}\text { Prior knowledge is a mean to make sense of the } \\
\text { world and support discovery and exploitation of } \\
\text { opportunities. Individuals retrieve knowledge from } \\
\text { their memory and apply it to the specific situation. }\end{array}$ \\
\hline
\end{tabular}

Source: own study. 
Gollwitzer et al., (1990). Even though these experiments were done with students to explore working of the mindset per se, they delivered a valuable basis for later research on the EM concept.

The details of the empirical studies included in this study have been provided in Table 4.

\section{Definitions of Entrepreneurial Mindset}

EM definitions existing in the literature are more or less similar to each other (Table 5). EM is seen as a way of adaptable thinking and decision-making in complex, uncertain and dynamic environments. McGrath and MacMillan (2000, p. 15) defined the entrepreneurial mindset as the "ability to rapidly sense, act, and mobilize, even under highly uncertain conditions". According to them, entrepreneurs stay alert to new opportunities, but do not pursue all of them at the same time. Instead, they are aware of their scarce resources and strictly focus them on those projects which are aligned with their strategy and promise the highest return. Implementing these projects requires them to be adaptive to the evolving reality to ensure the best exploitation of opportunities. For this, they leverage their existing internal and external social networks (McGrath \& MacMillan, 2000).

Ireland et al., (2001, p. 968) explained EM as a "way of thinking" which creates (competitive) advantage out of the positive aspects of uncertainty. Meaning is created even in complex and equivocal situations through cognitive abilities. Ireland et al. did not limit EM to entrepreneurs, but extend it to managers and employees of established companies. Haynie and Shepherd (2007, p. 9) argued that EM is an outcome of meta-cognitive awareness as it is the "ability to adapt thinking process to a changing context and task demands". In 2010 Shepherd et al., (p. 62) further refined their definition and suggested that the "ability to rapidly sense, act, and mobilize" is a response to a decision made under uncertainty to exploit an opportunity.

Baron (2014) stressed the uniqueness that entrepreneurs create by the way they "think, reason, make decisions, plan and set goals". They are able to connect apparently unrelated patterns through the use of their internal frameworks, which are shaped by experience, knowledge, heuristics and networks. The environments they are in make a different way of thinking necessary. When they translate their ideas into reality they do not use usual causeand effect logics, but connect information in a different way (Baron, 2014).

McMullen and Kier (2016, p. 664) agree by stating that the EM is the "ability to identify and exploit opportunities without regard to the resources currently under their control". However, they make an important distinction by arguing that EM is only working when entrepreneurs experience promotion focus. Promotion focus means that people strive for pleasure. In the area of entrepreneurs this could be the return of maximisation or achievements. Entrepreneurial actions and motives are focused on achieving that. Distinguished from that is prevention focus. Here, people focus on safety in order to avoid pain, or, in terms of entrepreneurs, financial losses (Higgins, 1997).

Davis et al., (2016) stated that EM is a "constellation of motives, skills, and thought processes that distinguish entrepreneurs from nonentrepreneurs" (p. 2).

All definitions presented by the various authors emphasise that EM is strongly associated with thinking. Some extend it by acting and the uniqueness in which entrepreneurs leverage and link resources to exploit opportunities. Following these definitions it can be said that the current EM concept is based on a cognitive perspective. 
Table 5. Definitions of entrepreneurial mindset (EM) in the literature

\begin{tabular}{|l|l|}
\hline \multicolumn{1}{|c|}{ Author } & \multicolumn{1}{c|}{ Definition } \\
\hline $\begin{array}{l}\text { McGrath \& MacMillian } \\
(2000, \text { p. 15) }\end{array}$ & "ability to sense, act, and mobilize under uncertain conditions" \\
\hline $\begin{array}{l}\text { Ireland, Hitt, \& Sirmon } \\
\text { (2001, p. 968) }\end{array}$ & $\begin{array}{l}\text { "way of thinking about business that focuses on and captures benefits of } \\
\text { "growth-oriented perspective through which individuals promote flexibil- } \\
\text { ity, creativity, continuous innovation, and renewal" }\end{array}$ \\
\hline $\begin{array}{l}\text { Haynie \& Shepherd } \\
\text { (2007, p. 9) }\end{array}$ & “ability to adapt thinking process to a changing context and task demands" \\
\hline $\begin{array}{l}\text { Dhliwayo \& Van } \\
\text { Vuuren (2007, p. 124) }\end{array}$ & "way of thinking and acting about business" \\
\hline $\begin{array}{l}\text { Shepherd, Patzelt, \& } \\
\text { Haynie (2010, p. 62) }\end{array}$ & $\begin{array}{l}\text { "ability and willingness of individuals to rapidly sense, act, and mobilize in } \\
\text { response to a judgmental decision under uncertainty about a possible op- } \\
\text { portunity for gain" }\end{array}$ \\
\hline Baron (2014, p. 55) & "think, reason, make decisions, plan and set goals in relatively unique way" \\
\hline $\begin{array}{l}\text { Davis, Hall, \& Mayer } \\
(2016, \text { p. 2) }\end{array}$ & $\begin{array}{l}\text { "constellation of motives, skills, and thought processes that distinguish } \\
\text { entrepreneurs from nonentrepreneurs" }\end{array}$ \\
\hline $\begin{array}{l}\text { McMullen \& Kier } \\
\text { (2016, p. 664) }\end{array}$ & $\begin{array}{l}\text { "ability to identify and exploit opportunities without regard to the re- } \\
\text { sources currently under their control”, only working when entrepreneurs } \\
\text { experience promotion focus }\end{array}$ \\
\hline
\end{tabular}

Source: own study.

\section{Attributes Influencing Entrepreneurial Mindset}

In a textual analysis of the cognitive-based papers a list of EM attributes and their associated qualities emerged. An attribute is herein defined as an internal characteristic which shapes EM. The different attributes make up the building blocks of the overall EM concept. Associated qualities are the exhibited human behaviour of these attributes.

Overall, seven attributes and associated qualities evolved (Table 6).

Five attributes refer to cognitive processes which have a direct effect on the exhibited human behaviour and can be observed from the outside. These five will be referred to as core attributes of EM. The other two require higher levels of self-awareness and are more hidden. They are less exhibited in behaviour and therefore harder to recognize from the outside. These two will be referred to as meta-cognitive attributes of EM.

The first attribute of EM is the cognitive tuning and goal orientation of the mindset. A key characteristic of the mindset is that it changes over time depending on the activity an individual is in. The mindset influences individuals' cognition for that activity (Gollwitzer, 1990). This individuals' cognition is tuned towards that activity to ensure that the task at hand is done most effectively. Mindsets and cognitive processes are thus congruent (Gollwitzer et al., 1990). Entrepreneurial mindsets have been differentiated into a deliberative (elaborative) and implemental mindset (Mathisen \& Arnulf, 2013; McMullen \& Kier, 2016). The deliberative mindset is impartial and open-minded. Individuals in this mindset evaluate the positive and negative effects of a decision to be taken and the desired goal in regards to its feasibility and desirability. In this mindset goals are set. In the implemental mindset individuals are striving towards goal achievement and process 
Table 6. Attributes and associated qualities influencing EM

\begin{tabular}{|c|c|c|}
\hline No. & Attribute & Associated qualities \\
\hline 1 & $\begin{array}{l}\text { Cognitive } \\
\text { tuning and goal } \\
\text { orientation }\end{array}$ & $\begin{array}{l}\text { - Thinking is tuned to the mindset at work } \\
\text { - Ensure high effectiveness to solve a task at hand } \\
\text { - Differentiates between cautious and eager goal-setting and goal-striving }\end{array}$ \\
\hline 2 & $\begin{array}{l}\text { Heuristic-based } \\
\text { decision logic }\end{array}$ & $\begin{array}{l}\text { - Fast decision-making based on heuristics and biases } \\
\text { - Effective and efficient under high complexity and uncertainty }\end{array}$ \\
\hline 3 & Alertness & $\begin{array}{l}\text { - Sudden insights of value } \\
\text { - Attentiveness }\end{array}$ \\
\hline 4 & Prior knowledge & $\begin{array}{l}\text { - Abstract knowledge to combine and use existing but disparate resources } \\
\text { - Influenced by experience, education, knowledge }\end{array}$ \\
\hline 5 & $\begin{array}{l}\text { Social } \\
\text { interaction }\end{array}$ & - Access to disparate information across the own social network \\
\hline 6 & Meta-cognition & $\begin{array}{l}\text { - Reflection about own thinking process } \\
\text { - Flexibility to use different strategies to solve a task dependent on the situation }\end{array}$ \\
\hline 7 & $\begin{array}{l}\text { Cognitive } \\
\text { adaptability }\end{array}$ & $\begin{array}{l}\text { - Depends on meta-cognitive experience and knowledge and can be } \\
\text { improved by developing meta-cognition } \\
\text { - Facilitates efficiency } \\
\text { - Being flexible and self-regulating in uncertain situations }\end{array}$ \\
\hline
\end{tabular}

Source: own study.

information related to where, how and when the goal is implemented. The decision is made and they act on it. This leads to a more partial and closed mindset (Mathisen \& Arnulf, 2013). The more determined individuals are in this implemental mindset, the more illusionary their judgment of control is (Gollwitzer \& Kinney, 1989). The goal orientation of both mindsets thus differs between goal setting (deliberative) and goal striving (implemental). McMullen and Kier (2016) broke down the goal orientation of both mindsets even more, into eager and cautious goal setting (deliberative) and striving (implemental). A cautious deliberative mindset avoids risk, whereas an eager deliberative mindset sets goals to maximise returns. A cautious implemental mindset is trying to minimise threats during implementation by doing contingency planning and net wealth framing in a cost-benefit analysis. An eager implemental mindset is strongly related to entrepreneurial activities. In this mindset entrepreneurs are particularly alert to opportunities. However, they also risk being locked in the situation and escalate their commitment due to their cognitive tuning to implementation, their illusion of control and too optimistic evaluation of the situation. They look for opportunities to maximise their goals and use gain-loss framing in a cost-benefit analysis. Their focus on promotion (for example profit maximisation) postpones a decision to stop pursuing the implementation even though it may lead to a dead-end. The adaptability of an entrepreneurial mindset is thus reduced when escalation of commitment occurs (McMullen \& Kier, 2016).

The second attribute is the heuristic-based decision-logic. The use of heuristics and biases is particularly effective and efficient in situations with high complexity and uncertainty. Entrepreneurs are facing both when making a decision. They need to make decisions quickly to use their window of opportunity and to encourage their stakeholders to trust them (Busenitz \& Barney, 1997). Beside complexity and uncertainty comes strong emotion and also time pressure, leading them more often to reach their cognitive limits. Due to that, entrepreneurs are prone to make use of heuristics and biases which are based 
on their beliefs and experiences to cope with complexity and to ensure fast decision-making (Baron, 1998). A heuristic often used by entrepreneurs is representativeness (Busenitz \& Barney, 1997). Representativeness is the willingness to generalise from small samples. Individuals tend to draw conclusions from few observations about people or of a situation and infer that this represents the reality (Kahnemann, 2013, p. 114).

As individuals experience situations differently, they make different decisions. The heuristic-based decision-logic of entrepreneurs is hard to imitate and thus often a source for competitive advantage (Alvarez \& Busenitz, 2001). Due to cognitive limitations of information processing, individuals are no rational decision-makers. This is even more relevant for entrepreneurs when faced with novel und uncertain situations without having the full information. Beside heuristics, entrepreneurs make use of biases to cope with complexity and to make decisions (Baron, 1998, 2014). Baron $(1998,2014)$ gave examples of typical biases used by entrepreneurs: entrepreneurs tend to pay the highest attention to information which confirms their own beliefs and experiences and avoid accepting information which challenges their belief (confirmation bias). They often accredit positive outcome to their talents and strengths and negative outcomes to external developments or facts (self-serving bias). Entrepreneurs often expect more positive results which would be rationally reasonable (optimistic bias). Their fast thinking enhances their risk-taking even though they might not perceive it as a risk (fast thinking effect). And, they are prone to get trapped in a situation when a decision is made (sunk cost). Another bias often used is overconfidence, which is the exaggerated opinion that one has fully understood a situation or behaviour of a person and starts acting on it without having all the information available. The principles are understood and a decision can be made. The inclusion of new information is delayed (Busenitz \& Barney, 1997).

The third attribute is alertness. It can be traced back to Kirzner (1973) who discussed that it is not the possession of knowledge that leads to the identification of opportunities, but the alertness to the information. Alvarez and Busenitz (2001) conceptualise alertness as sudden insights or recognition of value of a product or service, and Ireland et al. (2003) as the ability to identify value unexpectedly. It is the "attentiveness to new opportunities" (Mitchell et al., 2002, p. 7). Alertness was also an important component in the pattern recognition model developed by Baron (2006). He defined alertness as the capacity to recognize opportunities when they emerge. Due to Baron (2006), this alertness is partly a cognitive ability, influenced by personal capabilities like intelligence and creativity. Beside alertness there is active, systematic search for information. Baron argued that active search is less necessary when alertness is very high. He theorised whether alertness would be higher for habitual entrepreneurs than for those creating a company for the first time. The growth of alertness capacity was also signalled by Żur (2015), as with time, experience and entrepreneurial learning processes the entrepreneur moves to higher levels of awareness and accuracy in opportunity identification (Wach, 2015).

The fourth attribute is prior knowledge. Prior knowledge is the combination of work experience, personal events and education (Shane, 2000), as well as social networks (Baron, 2006). As a result of these different sources, knowledge is created. All individuals possess different knowledge as they have access to different information and have different experiences in their life. They have accumulated that knowledge in a particular knowledge corridor which is specific to their circumstances (Shane \& Venkataraman, 
2000; Venkataraman, 1997). Baron (2014) specifies further that the long-term memory is factual or personal (explicit) knowledge and that it differs from the procedural memory, which is expertise. The rapid access to this procedural memory is outside individuals' conscious awareness and makes them often unable to explain the source of this information. It is therefore also called intuition or tacit knowledge. Alvarez and Busenitz (2001) state that this explicit and tacit knowledge is an abstract knowledge about how to combine and use existing but disparate resources.

The fifth attribute of EM is social interaction or social capital. Social capital is created through cooperative trustful relationships with stakeholders and experience. Developing trustful relationships must also be seen as an investment as it requires time, energy and financial means. Particularly in uncertain and complex situations social capital is a differentiating factor for entrepreneurs (Venkataraman, 1997). It is also through these social interactions that entrepreneurs can access disparate information, make connections and see patterns evolve (Baron, 2006). They are able to leverage their networks and make use of the resources involved in unique and hard-to-imitate ways (Alvarez \& Busenitz, 2001).

The above explained five core attributes of EM. They all share a common characteristic: the effect of their respective cognitive processes translates into recognizable and observable behaviour. The following two meta-cognitive attributes of EM are more hidden. They need a higher level of self-awareness and eventually, development over time through feedback and learning cycles. The strength of these two attributes then impacts the other five as well.

The first meta-cognitive attribute is the metacognition itself. Metacognition is the "thinking about thinking" (Flavell 1979, 1987; Haynie et al., 2010) and applying different strategies depending on the context and task. According to Haynie et al., (2012), entrepreneurs differ in their thinking and acting from non-entrepreneurs through their different meta-cognitive abilities and interpretation of the environment. As the environment and internal motivation of every individual is different, everyone develops different strategies in different situations. By reflecting on their own thinking process prior to decision-making, entrepreneurs can adapt their cognition and consequently their actions.

The second meta-cognitive attribute is cognitive adaptability, which is a result of the meta-cognitive thinking process (Haynie \& Shepherd, 2009). Cognitive adaptability is the "ability to be dynamic, flexible, and self-regulating in one's cognitions given dynamic and uncertain task environment" (Haynie, Shepherd, Mosakowski, \& Earley, 2010 , p. 218). It depends first on the individuals' meta-cognitive awareness (awareness about own thought process) and second on meta-cognitive resources consisting of meta-cognitive knowledge (about people, task and cognitive strategies) and metacognitive experience (memories, emotions about former, similar tasks). The higher the uncertainty in a situation is, the higher the awareness is, and the more strategies will be applied in the thought process (e.g. scenario planning, brainstorming). The higher the meta-cognitive awareness, the more it is necessary to use meta-cognitive resources. Individuals who use meta-cognitive resources process environmental feedback more effectively and can adapt their decision-making accordingly. Particularly for inexperienced entrepreneurs meta-cognitive abilities are important for their performance as they can counter-balance the lack of experience in the field.

The discussed definitions, attributes and their associated qualities reveal that state-of-the-art research of the EM concept is based on a cognitive perspective. For 
that reason, this research stream is referred to as cognitive-based in this paper. Looking at the list of attributes and qualities, the authors of this stream seek to explain why entrepreneurs decide and act in a specific way.

Based on the literature review, Figure 2 provides an overview of how the seven attributes of EM link together.

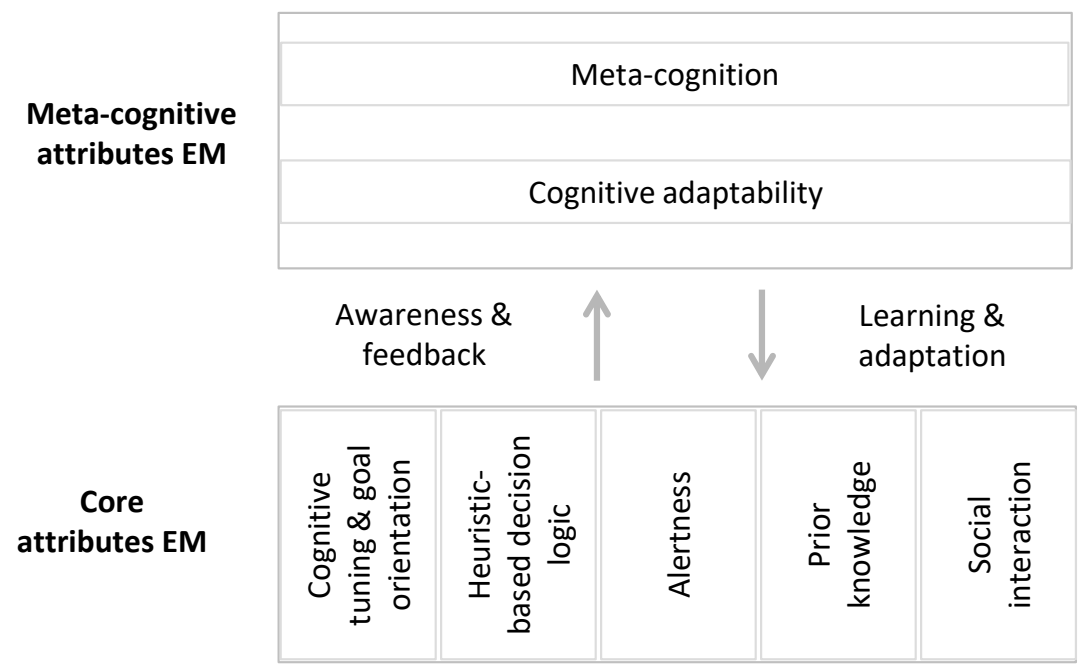

Figure 2. Linkage of the EM attributes based on the Literature Review Source: own study.

The meta-cognitive attributes of EM relate to thinking-about-thinking. They determine how an individual approaches a task. Depending on the level of the individuals' meta-cognitive awareness, the awareness of own cognitive processes exists and feedback can be processed effectively. Depending on the level of the individuals' cognitive adaptability, influenced by the mindset which is in it, learning is applied and cognitive processes and thus exhibited behaviour adapted.

\section{The EM Concept Development and Limitations}

The approach to answer the question of why entrepreneurs are able to detect and exploit opportunities better than others started by the end of the 1980s when scholars coming from the behavioural science background entered the field of entrepreneurship. According to Gartner (1989), entrepreneurs seemed to be very heterogeneous. And Shaver and Scott (1991) stipulated it is the psychological process of a person in a specific situation and the choices involved which determine who becomes a successful entrepreneur.

Based on the literature review, Figure 3 provides an overview of the development of the cognitive-based approach since then and puts the research done on particular EM attributes in the perspective with the classification of the papers (see also Table 2).

Figure 3 shows that the research field of the EM concept is widely spread over the last decades. Scholars investigated especially the particular attributes, but did not put the pieces together to a commonly shared concept of EM. 
Gollwitzer \& Kinney (1989), Gollwitzer (1990), Gollwitzer, Heckhausen, Steller (1990)

Characteristics of mindsets and cognitive tuning

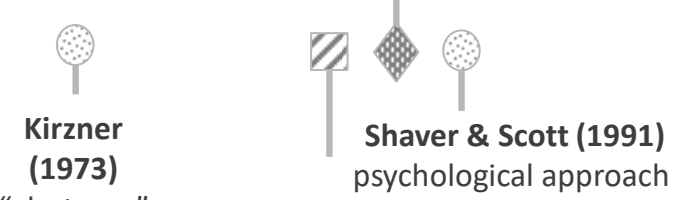

psychological approach

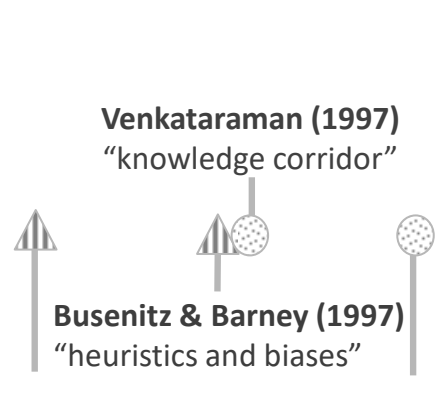

Simon et al. (2000)

Mitchell \& Busenitz

"alertness" Gartner (1988)

Behavioral theory for

entrepreneurship
Palich \& Bagby (1995)

cognitive

categorization

\section{Baron (1998) \\ "biases"}

"biases"

"biases" Shane (2000) "entrepreneurial "prior knowledge" cognition"

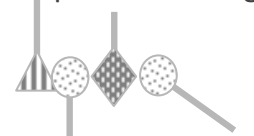

McGrath \&

Shane \&

MacMullen (2000) Venkataraman
Definition
entrepreneurial
mindset
Mathisen \& Arnulf (2013)

"cognitive tuning and goal setting"

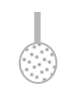

Haynie \& Shepherd (2009)

Meta-cognition

Measure of cognitive adaptability

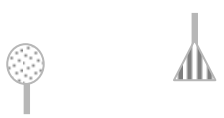

Baron (2014)

"cognitive bias"<smiles>C#CC#C</smiles>

Haynie et al. (2012)

"meta-cognition"

"cognitive

adaptability"

Conceptual
Systematic review "feedback loops"

Haynie et al. (2010)

"cognitive

adaptability"
Shepherd et al. (2010)

$$
\text { (1). Explanatory }
$$

Haynie et al. (2007) frameworks" Meta-cognition

Metacognitive feedback

\section{Mitchell et al.}

(2007)

"entrepreneurial

cognition"

Exploratory

Figure 3. Development of the cognitive research stream

Source: own study. 
Despite the research done, there are still areas which remain under-addressed. First, the research design and samples chosen by authors pursuing explanatory and exploratory research only once made use of in-depth interviews with eight entrepreneurs (Shane, 2000). Taking into account the "law of small numbers" (Kahnemann, 2013), this is not a representative sample. More qualitative research could provide an in-depth understanding of the EM attributes and the interactions between the EM attributes and their associated qualities. Qualitative studies can better explore the circumstances out of which these attributes arise and specifically how the core and meta-cognitive attributes influence each other. Qualitative interviews could help to put entrepreneurs' behaviour in the perspective of their environment. For example, it would be interesting to see whether the attributes are differently exhibited for novice or habitual entrepreneurs, for entrepreneurs in different industries or in different phases of the business lifecycle. This would also address the limitation of the samples used in previous papers where for two out of three times students were taken to explain entrepreneurial behaviour. Although more qualitative research could deliver more in-depth insights into the EM concept, this research design also has its drawbacks in this context. The concept of EM is cognitive-based and the specifics of an EM depend largely on the personal situation of an entrepreneur. Along with the fact that due to the intensity of the in-depth interviews only small samples can be used, the results are hardly generalisable. Furthermore, interviewees might be biased. They might want to prove that they are special. Hence, the interviewer must be well trained and the aim of the interview not transparently communicated. These limitations to in-depth interviews might be as well the cause why it was done only once in the past. However, this should not be the reason to shy away from qualitative research. Future research can also use in-depth interviews to develop theories and then test them in a quantitative research design.

The second limitation of previous papers is the limited timeframe used by scholars. Only once was a longitudinal design used. Considering the definition by McGrath and MacMillan (2000) about the adaptability of the mindset, it is surprising how under-studied this adaptability actually is. Additionally, having only one week in between two experiments is not enough to observe a shift in the mindset. It would be interesting to see whether EM changes over the course of three months to three years with the same sample of entrepreneurs. Three months are a long time in the start-up environment, but it would be interesting to see how the mindset of founders changes over even a longer period of time. Alternatively, this exploration can be done with entrepreneurs who are in different stages of the business lifecycle. Future research might investigate more how EM evolves to understand the dynamics of it. It is important to understand if EM changes over time and whether this development is homogenous across different groups of entrepreneurs. In this regard, it would be interesting to understand the antecedents which shape the rise of EM. This knowledge would also be of importance for the entrepreneurial education.

The third area which remains under-addressed by past papers also represents the main limitation to this study. The databases used are mainly for English texts leading to a strong Anglo-American perspective on the state-of-art in the EM research. National databases which include native language texts, for example in the national libraries of Poland, China or Germany may include other and different research performed on the topic. The papers reviewed had also a strong focus on the US. Future 
research could therefore investigate EM in other cultures or with people from other cultural backgrounds to validate the existing findings.

\section{The Linkage of the EM Concept to Other Research Areas}

Based on the literature review, it appears that the EM concept is also linked to mainly four other areas of research (Figure 4).

The combined approach which links the entrepreneurial trait theory and the EM concept. Scholars in this field base their research on the assumption that personal traits indirectly affect entrepreneurial outcomes through mediators. In the past, typical traits analysed was the need for achievement (McClelland, 1961), assertiveness (McClelland, 1987) and risk taking propensity (Brockhaus, 1980). Davis et al., (2015) used the Five-Factor-Model (FFM) which describes the five personality dimensions as the basis, and specific traits in each of the dimensions to analyse the link between personality characteristics and entrepreneurial outcomes. They proposed the 'Entrepreneurial Mindset Profile' (EMP) in which traits and skills are measured. They distinguish between the two as they argue that entrepreneurial intention is coming from personality but individuals are good entrepreneurs because of their skills. While skills can be improved through training, traits are part of personality. The authors' explanatory research concluded that traits have a stronger effect on entrepreneurial status. In relation to the five personality dimensions, Openness to Experience had the strongest association with the EMP scales and Extraversion had the weakest. Also Ashourizadeh et al., (2014) provided a similar perspective, stating that the intention to become an entrepreneur is promoted by EM. They studied the effect of confidence in innovation $(\mathrm{Cl})$, perceived as a component of $\mathrm{EM}$, on the intention to become an entrepreneur, but also included traits (like risk taking propensity) into their model. They concluded that $\mathrm{Cl}$ is influenced by culture and gender and ultimately affects intention.

The use of mediators in the combined approach provides an interesting avenue as it could explain why previous research in the trait-based approach, where only direct links were tested, provided so unconvincing results (Busenitz \& Barney, 1997; Gartner, 1989; Shaver \& Scott, 1991). However, more empirical studies would be required to identify the relevant mediators.

Second, EM was linked to the resource-based theory (RBT). The resource-based theory assumes that companies analyse and focus their core competencies and capabilities (resources) to the exploitation of identified market opportunities in order to achieve competitive advantage (Thompson \& Martin, 2005). The combination of resources is different among companies. They can be tangible or intangible. Rare resources are a source for developing a competitive advantage (Ireland, Hitt, \& Sirmon, 2003). Alvarez and Busenitz (2001) investigated the relationship between entrepreneurship and the RBT and argued that the entrepreneurial recognition of opportunities is a resource in itself. They stated that if entrepreneurs possess a "unique mindset" with specific cognitive processes this would form a source for competitive advantage. The cognitive abilities of entrepreneurs help them to identify opportunities and organise resources for the firm. Understanding the antecedents of EM and further investigation of the link to the RBT could strengthen that strategic resource for a company.

Third, EM was included as an important aspect of strategic entrepreneurship. Ireland et al., (2003) explain strategic entrepreneurship as a construct which seeks to support small and medium-sized companies and large firms to build competitive advantage and thus wealth. Their model combines the overlapping elements of entrepreneurship and strategic management and includes the aspects of the RBT beside organisational learning, EM and entrepreneurial leadership to develop a competitive advantage for the firm. Again, 
understanding how the attributes of EM arise and can be shaped would be an important element in this research area as EM is a critical element of the model.

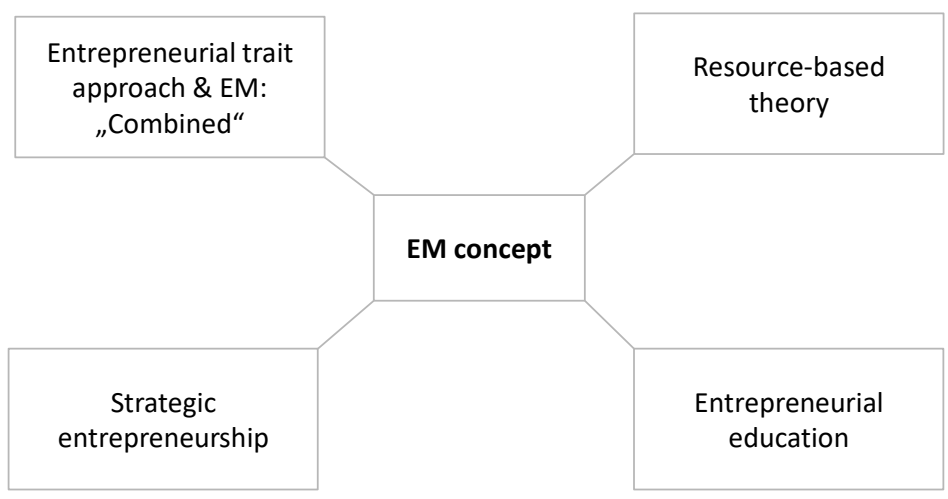

Figure 4. Linkages of the EM concept to other streams of research Source: own study.

Fourth, EM has been related to entrepreneurial education. Wach and Wojciechowski (2016) emphasised that EM is influencing entrepreneurial intentions. Thus, crafting EM already in the education system is of utmost importance. Ngek (2012) assessed the relationship between entrepreneurial education and the factors shaping EM. He argued that factors like creativity, motivation and risk-propensity, when properly supported by education, could shape EM. Entrepreneurial education would be relevant for founders of new ventures, corporate businesses and students. Given the dynamics and complexities, as well as the speed in which disruptions of industries happen in today's business environment, an understanding of the overall EM concept and its driving factors can enable more effective entrepreneurial education. The link to this research stream seems to offer one of the best avenues for future research as it can contribute to the other research areas given here as well. Developing an EM through effective entrepreneurial education already in school could enhance the adaptability of individuals' mindset in a fast-changing world later on. Strengthening it before and during the foundation of a new business can reduce the high failure rates of start-ups. Shaping EM in a corporate environment can improve adaptability and the building of strategic resources in the sense of the RBT in order to exploit new opportunities and cope with the high dynamics of the business world.

\section{CONCLUSIONS}

The aim of this paper was to provide an overview of the state-of-the-art of the EM concept. The synthetic literature review identified several types of papers based on two driving criteria: sub-stream of EM research and the main goal of the study. The review led to identifying a list of attributes and associated qualities of EM, which are described in detail in this study. It highlighted the differentiation between the core attributes of EM and the meta-cognitive attributes of EM. While core attributes are easier to recognize through exhibited behaviour, meta-cognitive attributes are more hidden and require a higher level of self-awareness. The literature review provided an overview of the development of the EM concept and worked 
out that currently no commonly shared concept of EM exists. Instead, scholars have investigated especially on the particular attributes. By connecting them and outlining the development of the EM concept until this date, the paper presents where we are today.

An important step in the research of EM would be to focus next on the antecedents and the dynamics of EM. The understanding of what creates and shapes EM would then contribute largely to the entrepreneurial education. An effective education would then positively impact other areas like strategic entrepreneurship or the RBT.

\section{REFERENCES}

Alvarez, S., \& Busenitz, L.W. (2001). The entrepreneurship of resource-based theory. Journal of Management, 27(October), 755-775. https://doi.org/10.1177/014920630102700609

Ashourizadeh, S., Chavoushi, Z.H., \& Schøtt, T. (2014). People's confidence in innovation: a component of the entrepreneurial mindset, embedded in gender and culture, affecting entrepreneurial intention. International Journal of Entrepreneurship and Small Business, 23(1/2), 235. https://doi.org/10.1504/IJESB.2014.065310

Baron, R.A. (1998). Cognitive mechanisms in entrepreneurship: Why and when enterpreneurs think differently than other people. Journal of Business Venturing, 13(4), 275-294. https://doi.org/10.1016/S0883-9026(97)00031-1

Baron, R.A. (2006). Opportunity Recognition as Pattern Recognition: How Entrepreneurs "Connect the Dots" to Identify New Business Opportunities. Academy of Management Perspectives, 20(1), 104-119. https://doi.org/10.5465/AMP.2006.19873412

Baron, R.A. (2014). Cognitive foundations of Entrepreneurship. In Essentials of Entrepreneurship. Evidence and Practice (1st ed., pp. 3-58). Cheltenham: Edward Elgar.

Brockhaus, S.R.H. (1980). Risk taking propensity of entrepreurs. Academy of Management Journal, 23, 509. Retrieved on June 6, 2017 from http://search.epnet.com/login.aspx?direct $=$ true $\& d b=$ buh $\& a n=4395849$

Busenitz, L.W., \& Barney, J.B. (1997). Differences between entrepreneurs and managers in large organizations: Biases and heuristics in strategic decision-making. Journal of Business Venturing, 12(1), 9-30. https://doi.org/10.1016/S0883-9026(96)00003-1

Davis, M.H., Hall, J.A., \& Mayer, P.S. (2015). Developing a new measure of entrepreneurial mindset: reliability, validity, and implications for practitioners. Consulting Psychology Journal: Practice and Research, (January). https://doi.org/10.1037/cpb0000045

Dhliwayo, S., \& Van Vuuren, J. (2007). The strategic entrepreneurial thinking imperative. Acta Commercii, 123134. Retrieved on June 6, 2017 from http://www.sabinet.co.za/abstracts/acom/acom_v7_a10.html

Flavell, J. (1979). Metacognition and cognitive monitoring: a new area of cognitive-developmental inquiry. American Psychologist, 34 (10), 906-911.

Flavell, J. (1987.) Speculations about the nature and development of metacognition. In F.E. Weinert \& R.H. Kluwe (Eds.), Metacognition, Motivation, and Understanding. Hillside, NJ: Erlbaum.

Gartner, W.B. (1989). "Who is an Entrepreneur?" is the wrong question. American Journal of Small Business, 13(Spring), 11-32. https://doi.org/10.1210/jc.2003-031037

Gollwitzer, P.M. (1990). Action Phases and Mind-Sets. In Handbook of Motivation and Cognition. Foundations of Social Behavior. Max-Planck-Institut für psychologische Forschung (Vol. 2, pp. 53-92). New York, London: Guilford Press. 
Gollwitzer, P.M., Heckhausen, H., \& Steller, B. (1990). Deliberative and Implemental Mind-Sets: Cognitive Tuning Toward Congruous Thoughts and Information. Journal of Personality and Social Psychology, 59(6), 1119-1127. https://doi.org/10.1037/0022-3514.59.6.1119

Gollwitzer, P.M., \& Kinney, R.F. (1989). Effects of Deliberative and Implemental Mind-Sets on Illusion of Control. Personality and Social Psychology Bulletin, 56(4), 531-542. https://doi.org/10.1177/014616702236868

Haynie, J.M., \& Shepherd, D.A. (2007). Exploring the entrepreneurial mindset: Feedback and adaptive decision-making. Frontiers: A Journal of Women Studies, 27(6), 1-15.

Haynie, J.M., \& Shepherd, D.A. (2009). A Measure of Adaptive Cognition for Entrepreneurship Research. ET\&P, (315), 695-715.

Haynie, J.M., Shepherd, D., Mosakowski, E., \& Earley, P.C. (2010). A situated metacognitive model of the entrepreneurial mindset. Journal of Business Venturing, 25(2), 217-229. https://doi.org/10.1016/j.jbusvent.2008.10.001

Haynie, J.M., Shepherd, D., Mosakowski, E., \& Earley, P.C. (2010). A situated metacognitive model of the entrepreneurial mindset. Journal of Business Venturing, 25(2), 217-229. https://doi.org/10.1016/j.jbusvent.2008.10.001

Haynie, J.M., Shepherd, D.A., \& Patzelt, H. (2012). Cognitive Adaptability and an Entrepreneurial Task: The Role of Metacognitive Ability and Feedback. Entrepreneurship Theory \& Practice, 36(2), 237-265.

Higgins, E.T. (1997). Beyond pleasure and pain. American Psychologist, 52(12), 1280-1300.

Ireland, R.D., Hitt, M.A., \& Sirmon, D.G. (2003). A model of strategic enterpreneurship: The construct and its dimensions. Journal of Management, 29(6), 963-989. https://doi.org/10.1016/S0149-2063(03)00086-2

Kahnemann, D. (2013). Thinking fast and slow (1st ed.). New York: Farrar, Straus and Giroux.

Kirzner, I. (1973). Competition and Entrepreneurship. Chicago - London: The University of Chicago Press.

Mathisen, J.-E., \& Arnulf, J.K. (2014). Entrepreneurial Mindsets Theoretical Foundations and Empirical Properties of a Mindset Scale. The International Journal of Management and Business, 5(1), 81-97.

Mathisen, J.E., \& Arnulf, J.K. (2013). Competing mindsets in entrepreneurship: The cost of doubt. International Journal of Management Education, 11(3), 132-141. https://doi.org/10.1016/j.jjme.2013.03.003

McClelland, D.C. (1961). The achieving society. Princeton: Van Nostrand.

McClelland, D.C. (1987). Characteristics of successful entrepreneurs. Journal of Creative Behavior, 21, 219-233.

McGrath, R.G., \& MacMillan, I.C. (2000). The entrepreneurial mindset. Boston: Harvard Business School Press.

McMullen, J.S., \& Kier, A.S. (2016). Trapped by the entrepreneurial mindset: Opportunity seeking and escalation of commitment in the Mount Everest disaster. Journal of Business Venturing, 31(6), 663-686. https://doi.org/10.1016/j.jbusvent.2016.09.003

Mitchell, G.R. (2007). Instill the entrepreneurial mindset. Research Technology Management, 50(6), 11-13. Retrieved on June 6, 2017 from https://www.scopus.com/inward/record.uri?eid=2-s2.036749036029\&partnerID=40\&md5=36fef6bd5e0c15c32c8671c6d02efdc5

Mitchell, R.K., Busenitz, L.W., Theresa, L., McDougall, P.P., Morse, E.A., \& Smith, J.B. (2002). Toward a Theory of Entrepreneurial Cognition: Rethinking the People Side of Entrepreneurship Research. Entrepreneurship: Theory and Practice, (806), 93-104. https://doi.org/10.1111/1540-8520.00001

Ngek, B.N. (2012). An exploratory study on entrepreneurial mindset in the small and medium enterprise (SME) sector: A South African perspective on fostering small and medium enterprise (SME) success. African Journal of Business Management, 6(9), 3364-3372. https://doi.org/10.5897/AJBM10.1631

Palich, L.E., \& Ray Bagby, D. (1995). Using cognitive theory to explain entrepreneurial risk-taking: Challenging conventional wisdom. Journal of Business Venturing, 10(6), 425-438. https://doi.org/10.1016/0883-9026(95)00082-J 
Shane, S. (2000). Prior Knowledge and the Discovery of Entrepreneurial Opportunities. Organization Science, 11(4), 448-469. https://doi.org/10.1287/orsc.11.4.448.14602

Shane, S., \& Venkataraman, S. (2000). The promise of entrepreneurship as a field of research. Academy of Management Review, 25(1), 217-226.

Shaver, K.G., \& Scott, L.R. (1991). Person, Process, Choice: The Psychology of New Venture Creation Kelly G. Shaver. Entrepreneurship: Theory \& Practice, 16(2), 23-45.

Shepherd, D.A., Patzelt, H., \& Haynie, J.M. (2010). Entrepreneurial spirals: Deviation-amplifying loops of an entrepreneurial mindset and organizational culture. Entrepreneurship: Theory and Practice, 34(1), 59-82. https://doi.org/10.1111/j.1540-6520.2009.00313.x

Simon, M., Houghton, S.M., \& Aquino, K. (2000). Cognitive biases, risk perception, and venture formation: How individuals decide to start companies. Journal of Business Venturing, 15(2), 113-134.

Thompson, J., \& Martin, F. (2005). Key Strategic Concerns. In Strategic Management - Awareness and Change (5th ed., pp. 109-141). South Western: Cengage Learning.

Venkataraman, S. (1997). The Distinctive Domain of Entrepreneurship Research. Advances in Entrepreneurship, Firm Emergence and Growth, 3(October), 119-138. https://doi.org/10.2139/ssrn.1444184

Wach, K. (2015). Entrepreneurial Orientation and Business Internationalisation Process: The Theoretical Foundations of International Entrepreneurship. Entrepreneurial Business and Economics Review, 3(2), 9-24. https://doi.org/10.15678/EBER.2015.030202

Wach, K., \& Wojciechowski, L. (2016). Entrepreneurial Intentions of Students in Poland in the View of Ajzen's Theory of Planned Behaviour. Entrepreneurial Business and Economics Review, 4(1), 83-94. http://dx.doi.org/10.15678/EBER.2016.040106.

Westhead, P., Ucbasaran, D., \& Wright, M. (2005). Decisions, actions, and performance: Do novice, serial, and portfolio entrepreneurs differ?. Journal of Small Business Management, 43(4), 393417. https://doi.org/10.1111/j.1540-627X.2005.00144.x

Żur, A. (2015). Opportunity Identification and Creation as Factors of Firm Internationalisation. Entrepreneurial Business and Economics Review, 3(2), 25-39. doi: 10.15678/EBER.2015.030203 


\section{Author}

\section{Christiane Naumann}

Contracted lecturer for Anhalt University of Applied Sciences (Germany) in the area of Leadership as well as Entrepreneurship in cooperation with Ghana Technology University College (Ghana). Selfemployed consultant for international Higher Education programs. Her current scientific interests include entrepreneurship, social entrepreneurship, leadership and change management.

Correspondence to: Mrs. Christiane Naumann, DCG Halle e.V. - International Institute - Beesener Straße 25, 06110 Halle (Saale), Germany, e-mail: dcgnaumann@t-online.de

\section{Acknowledgements and Financial Disclosure}

The author would like to thank Prof. Dr. Krzysztof Wach and Dr. Agnieszka Żur for their guidance and feedback. The author is also grateful to the Editors and the reviewers for their comments on the earlier version of this paper.

\section{Copyright and License}

This article is published under the terms of the Creative Commons

Attribution - NoDerivs (CC BY- ND 4.0) License

(1) (1) $\Theta$ http://creativecommons.org/licenses/by-nd/4.0/

Published by the Centre for Strategic and International Entrepreneurship - Krakow, Poland 